DOI: $10.22616 /$ REEP.2019.013

\title{
The Use of Information and Communication Technologies of Pedagogical Specialities Students in the Study Process
}

\author{
Juris Porozovs ${ }^{1}$ Dr. biol.; Aija Dudkina ${ }^{2}$ Dr. psych.; Alvis Valdemiers ${ }^{3}$ Mg. paed. \\ University of Latvia, Latvia \\ juris.porozovs@lu.lv¹; aija.dudkina@lu.lv²; alvis.valdemiers@lu.lv
}

\begin{abstract}
Information and Communication Technologies (ICT) are important for teachers because it needs to be effectively integrated ICT into the formal classroom teaching and learning conditions, so integration of ICT in teacher education is of great significance. The aim of the study was to compare the use and impact of the use of ICT on the study process of full-time (FT) and part-time (PT) pedagogical specialities students. The electronic survey of the 1st course pedagogical specialities FT and PT students from the University of Latvia was carried out. Altogether 118 students were questioned. The results of the research showed that the majority of surveyed pedagogical specialities students use ICT for study purposes 1-2 or 2-4 h during day. Different FT students use ICT more differently in comparison with PT students. FT students more often than PT students use ICT for different activities connected with study process but PT students in comparison with FT students more often use ICT for searching information to do home works. The majority of surveyed students evaluate their knowledge and skills in the using of ICT as good. The majority of students agree or rather agree that the use of ICT gives positive impact on different stages of the study process. The use of ICT helps better involvement in the study process, makes students more independent during study process, gives them possibilities to get more new information and better communicate during study process, the use of ICT makes studies more exciting and gives positive impact on the acquisition of the study content. More FT students (67\%) in comparison with PT students $(31 \%)$ agree that the use of ICT gives ability for better understanding of different processes and more FT students (45\%) in comparison with PT students ( $8 \%$ ) fully evaluate positive impact of the use of ICT on the acquisition of the study content. Students agree or rather agree to the negative impact of the use of ICT on the lifestyle. The results of the research suggest that the majority of pedagogical specialities students understand the necessity of acquiring ICT during study process.
\end{abstract}

Keywords: university education, students, ICT, positive impact, negative impact.

\section{Introduction}

The actual European Union Digital Agenda suggests to exploit in a better way the massive potential offered by information and communication technologies (ICT), with the view to promote innovation, economic growth and progress. For the university students, ICT is playing an important role, enabling them to acquire the necessary competences and skills required in their studies and/or for the nowadays digital world, targeting also on helping them to be easily inserted in the labour market after finishing their studies (Gorghiu, Gorghiu, Pascale, 2018). Teachers today are being forced to rethink the meaning of the terms 'literacy' and 'literacy education'. Traditional printed text as a primary means of communication, learning and information storage and transfer is rapidly being superseded. Technology is therefore shifting the ways in which people learn and communicate (Nettelbeck, 2005). Students see information and communication technologies (ICT) as a potential new way of fostering excellence and innovation, as well as an opportunity to challenge existing classroom practices. ICT plays a critical role in enhancing the teaching and learning processes of the distance education programmes (Owusu-Ansah, 2018).

Students' attitudes to computers in school are affected by their experience at home (Cullingford, Haq, 2009). If the students have had a great deal of experience, and use ICT at home, then they should be curious about what might be made new for them in the more erudite world of school. They might be aware of the great potential for computers in the teaching of a range of subjects or have had experience, not only through the World Wide Web, but also through television, of the rich presentations of historical facts, scientific wonders and well-illustrated accounts of other subjects. If they are innocent of such technology at home, they might arrive with either great hope or greater apprehension. The prior knowledge and awareness of using ICT by students is important (Cullingford, Haq, 2009). There are significant differences between schools in terms of students' ICT usage, both for entertainment and 
school-related tasks. The only school-related factor that seems to be important for students' ICT usage is the student's involvement in ICT-related tasks at school (Gumus, 2013).

Didactic usability of the ICT is suggested by L. Dauvarte and V. Dislere in Home economics and technologies lessons for preparing video material and creation of presentations; for implementation of practical workshops: creation of different compositions, drawing, designing patterns for clothing, testbuilding in e-environment. The most important thing in any learning process about didactic usability of ICT is to prepare teachers to understand their teacher's role and learn to respect the learners' autonomy, authenticity, learning styles and motivation (Dauvarte, Dislere, 2015). Recently, the use of ICT in career counselling as an additional consultancy technique at school has become popular. ICT-based e-guidance is fast developing both in schools and for adults (Racene, Dislere, 2014).

Different investigations have shown that the use of ICT positively affects students' academic achievements (Nwosu et al., 2018; Ishtiaq et al., 2017) and improve students' learning motivation (Becta ICT Research, 2003). However, the efficiency of ICT usage to a large extent depends on how well educators and students can use modern technologies (Mamani, Cipi, 2013). Surveys of students suggest that students consistently prefer their instructors to use ICT in their teaching, including lectures as well as individual and group work in class (Fichten et al., 2015). There are some technologies that students say work well for them but not many professors use in their teaching, such as online tests/quizzes, podcasts, and clickers. However, there are technologies that both students and professors agree did not facilitate learning, such as digital text books, blogs and chat rooms (Fichten et al., 2018). Highlights of the student surveys indicate that there are no significant differences between nationalities and genders in their attitude to the use of ICT in study process (King et al, 2017). The findings show that there is no significant difference in the attitude of bachelor education students towards ICT with regard to discipline, course of study, gender, locality, and aided colleges of education but bachelor education students are better than college students in their attitude towards ICT (Sekar, Lawrence, 2015). Students ICT availability at school is positively associated with student academic success, whereas student ICT availability at home is negatively associated with student academic success (Hu et al, 2018).

Teacher education consists of sets of events and activities, which are deliberately intended to help candidates to acquire the skills, dispositions, knowledge, habits, attitudes values, norms, which enable them to enter the occupation of teaching (Sekar, Lawrence, 2015). ICT exemplified by the internet and interactive multimedia are obviously of great significance for teachers. It needs to be effectively integrated ICT into the formal classroom teaching and learning conditions. The integration of ICT in teaching in general and teacher education in particular is the need of the day. Its adequate recognition and fulfilment of relevant needs is crucial for integration and effective utilization of quality education programmes (Sekar, Lawrence, 2015).

The aim of the study was to compare the use and impact of the use of ICT on the study process of fulltime and part-time pedagogical specialities students.

\section{Methodology}

The electronic survey of the $1^{\text {st }}$ course pedagogical specialities full-time (FT) and part-time (PT) students from the University of Latvia was carried out. Altogether 118 students were questioned (52 FT students and 66 PT students). The survey was worked out in order to clarify the time, which pedagogical specialities students spend using ICT for purposes connected with study process and not connected with study process, the use of ICT by students for different activities connected with study process, the self-assessment of students' knowledge and skills in the using of ICT and evaluation of students' attitude to positive and negative impact of the use of ICT on the study process. The answers of FT and PT students were compared.

SPSS statistical data processing program was used for statistical analysis. Mann-Whitney U test was used for data analysis.

The research question was: how much students use ICT and what is the attitude of students to the use of ICT during study process?

\section{Results and Discussion}

The results of investigation showed that the majority of surveyed pedagogical specialities students use ICT for study purposes 1-2 or 2-4 hours (h) during day (Figure 1). Thirty nine percent of part time (PT) 
students use ICT $1-2 \mathrm{~h}$ during day and $46 \%$ of them use ICT $2-4 \mathrm{~h}$ during day. Different full time (FT) students use ICT more differently in comparison with PT students. Twenty-two percent of surveyed FT students use ICT less than $1 \mathrm{~h}$ during day, $45 \%$ of them use ICT $1-2 \mathrm{~h}$ during day, $11 \%$ of students use ICT 2-4 h during day but $22 \%$ of FT students use ICT for study purposes more than $4 \mathrm{~h}$ during day.

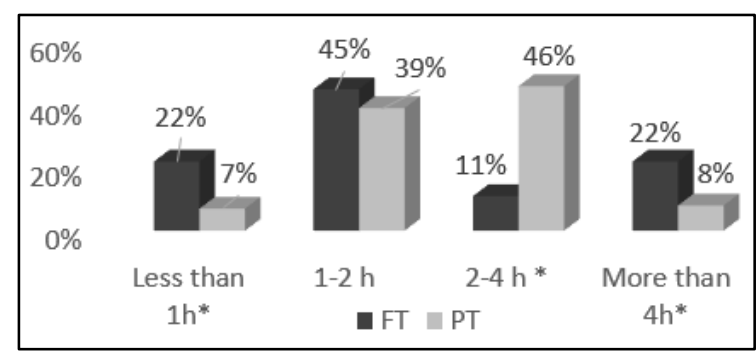

Figure 1. The use of ICT by students for study purposes (in \% from the number of respondents) $(* \mathrm{p}<0,05)$.

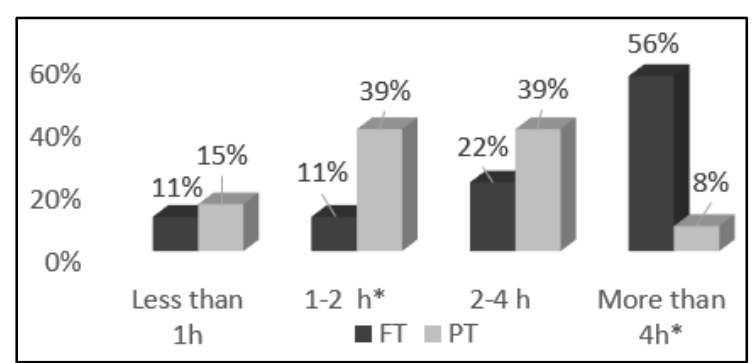

Figure 2. The use of ICT by students not connected with study purposes (in $\%$ from the number of respondents) $(* \mathrm{p}<0,05)$.

FT students use ICT more than PT students for purposes not connected with study process (Figure 2). $56 \%$ of FT students use ICT for purposes not connected with studies more than $4 \mathrm{~h}$ during day but the majority of part time students until $4 \mathrm{~h}$ during day (39\% of PT students use $1-2 \mathrm{~h}$ during day and $39 \%$ 2-4 $\mathrm{h}$ during day).

FT students more often use ICT for different activities connected with study process (Table 1). The majority of FT students (67\%) use ICT to accomplish home works almost every day but the majority of PT students (62\%) use ICT to accomplish home works some times during week.

Table 1

The use of ICT by students for different activities connected with studies (in \% from the number of respondents) $(* \mathbf{p}<0,05)$

\begin{tabular}{|c|c|c|c|}
\hline \multirow[t]{2}{*}{ Activities } & \multirow[t]{2}{*}{ Answer } & \multicolumn{2}{|c|}{ Groups of students } \\
\hline & & FT students & PT students \\
\hline \multirow{4}{*}{$\begin{array}{l}\text { Accomplish home } \\
\text { works }\end{array}$} & Never & 0 & 0 \\
\hline & Some times during month * & 0 & 23 \\
\hline & Some times during week $*$ & 33 & 62 \\
\hline & Almost every day $*$ & 67 & 15 \\
\hline \multirow{4}{*}{$\begin{array}{c}\text { Searching } \\
\text { information for } \\
\text { doing home works }\end{array}$} & Never & 0 & 0 \\
\hline & Some times during month & 11 & 15 \\
\hline & Some times during week $*$ & 56 & 31 \\
\hline & Almost every day & 33 & 54 \\
\hline \multirow{4}{*}{$\begin{array}{l}\text { Contact with } \\
\text { people for carrying } \\
\text { out home works }\end{array}$} & Never & 0 & 15 \\
\hline & Some times during month * & 10 & 31 \\
\hline & Some times during week $*$ & 45 & 23 \\
\hline & Almost every day & 45 & 31 \\
\hline \multirow{4}{*}{$\begin{array}{c}\text { Make calculations } \\
\text { for doing home } \\
\text { works }\end{array}$} & Never & 22 & 31 \\
\hline & Some times during month & 11 & 15 \\
\hline & Some times during week & 45 & 39 \\
\hline & Almost every day & 22 & 15 \\
\hline \multirow{4}{*}{$\begin{array}{l}\text { Keep up study e- } \\
\text { environment }\end{array}$} & Never & 0 & 8 \\
\hline & Some times during month $*$ & 0 & 15 \\
\hline & Some times during week * & 0 & 23 \\
\hline & Almost every day $*$ & 100 & 54 \\
\hline
\end{tabular}

FT students also more often contact with people for carrying out home works, make calculations for doing home works and keep up study e-environment (100\% of FT students almost every day keep up 
study e-environment but only $54 \%$ of PT students do the same). The majority of PT students (54\%) almost every day search information for doing home works but the majority of FT students (56\%) search information for doing home works some times during week. Thirty three percent of FT students search information for doing home works almost every day.

The majority of students evaluate their knowledge and skills in the using of ICT for finding information as good (67 \% of FT students and $54 \%$ of PT students). More full-time students (45 \%) in comparison with parttime students $(23 \%)$ evaluate their knowledge and skills in the using of ICT for communication as excellent (Table 2).

Table 2

\section{Self-evaluation of knowledge and skills for using of ICT by students} (in $\%$ from the number of respondents) $(* p<0,05)$

\begin{tabular}{|c|c|c|c|}
\hline \multirow{2}{*}{$\begin{array}{l}\text { Kind of using of } \\
\text { ICT }\end{array}$} & \multirow[t]{2}{*}{ Knowledge and skills } & \multicolumn{2}{|c|}{ Groups of students } \\
\hline & & FT students & PT students \\
\hline \multirow{5}{*}{$\begin{array}{l}\text { Use of Microsoft } \\
\text { Office }\end{array}$} & No knowledge and skills & 0 & 0 \\
\hline & Bad & 0 & 0 \\
\hline & Medium & 33 & 31 \\
\hline & Good & 56 & 54 \\
\hline & Excellent & 11 & 15 \\
\hline \multirow{5}{*}{$\begin{array}{l}\text { Create multimedia } \\
\text { presentations (audio, } \\
\text { video, text) }\end{array}$} & No knowledge and skills & 11 & 8 \\
\hline & $\mathrm{Bad} *$ & 11 & 31 \\
\hline & Medium * & 11 & 23 \\
\hline & Good * & 67 & 31 \\
\hline & Excellent & 0 & 8 \\
\hline \multirow{5}{*}{$\begin{array}{l}\text { Evaluate the } \\
\text { credibility of the } \\
\text { found information }\end{array}$} & No knowledge and skills & 0 & 8 \\
\hline & Bad & 0 & 8 \\
\hline & Medium & 45 & 30 \\
\hline & Good & 45 & 54 \\
\hline & Excellent & 10 & 0 \\
\hline \multirow{5}{*}{$\begin{array}{l}\text { Use of ICT for finding } \\
\text { information }\end{array}$} & No knowledge and skills & 0 & 0 \\
\hline & $\mathrm{Bad}$ & 0 & 0 \\
\hline & Medium* & 11 & 46 \\
\hline & Good & 67 & 54 \\
\hline & Excellent $*$ & 22 & 0 \\
\hline \multirow{5}{*}{$\begin{array}{l}\text { Use of ICT for } \\
\text { communication }\end{array}$} & No knowledge and skills & 0 & 0 \\
\hline & Bad & 0 & 0 \\
\hline & Medium * & 22 & 8 \\
\hline & Good* & 33 & 69 \\
\hline & Excellent* & 45 & 23 \\
\hline
\end{tabular}

The majority of surveyed students agree or rather agree that the use of ICT gives positive impact on the different stages of the study process (Table 3 ).

All FT students (100\%) and the majority of PT students (85\%) agree or rather agree that the use of ICT promotes better involvement of students in the study process. The majority of students (77 \% of FT students and $56 \%$ of PT students) fully agree that the use of ICT makes students more independent during study process. The majority of students rather agree (44\% of FT students and $54 \%$ of PT students) or agree (44\% of FT students and $31 \%$ of PT students) that the use of ICT gives ability for better acquiring of new information. The majority of students rather agree or agree that the use of ICT promotes better communication during study process ( $89 \%$ of FT students and $85 \%$ of PT students), and makes the learning process more exciting ( $81 \%$ of FT students and $76 \%$ of PT students). More FT 
students $(67 \%)$ in comparison with PT students (31\%) fully agree that the use of ICT promotes better understanding of different processes but more PT students (23\%), in comparison with FT students (8\%) rather do not agree to this consumption. It seems that FT students in comparison with PT students little higher evaluate the role of ICT in different stages of study process.

Table 3

The positive impact of the use of ICT by students on the different stages of the study processes (in $\%$ from the number of respondents) $(* \mathbf{p}<0,05)$

\begin{tabular}{|c|c|c|c|}
\hline \multirow[t]{2}{*}{ Activities } & \multirow[t]{2}{*}{ Answer } & \multicolumn{2}{|c|}{ Groups of students } \\
\hline & & FT students & PT students \\
\hline \multirow{4}{*}{$\begin{array}{l}\text { Better involvement in } \\
\text { the study process }\end{array}$} & Do not agree & 0 & 0 \\
\hline & Rather do not agree & 0 & 15 \\
\hline & Rather agree & 45 & 39 \\
\hline & Agree & 55 & 46 \\
\hline \multirow{4}{*}{$\begin{array}{l}\text { More independent } \\
\text { during study process }\end{array}$} & Do not agree & 0 & 5 \\
\hline & Rather do not agree & 0 & 0 \\
\hline & Rather agree & 23 & 39 \\
\hline & Agree & 77 & 56 \\
\hline \multirow{4}{*}{$\begin{array}{l}\text { Better acquiring of new } \\
\text { information }\end{array}$} & Do not agree & 12 & 0 \\
\hline & Rather do not agree & 0 & 15 \\
\hline & Rather agree & 44 & 54 \\
\hline & Agree & 44 & 31 \\
\hline \multirow{4}{*}{$\begin{array}{l}\text { Better communication } \\
\text { during study process }\end{array}$} & Do not agree & 11 & 0 \\
\hline & Rather do not agree & 0 & 15 \\
\hline & Rather agree & 33 & 39 \\
\hline & Agree & 56 & 46 \\
\hline \multirow{4}{*}{$\begin{array}{l}\text { Makes the learning } \\
\text { process more exciting }\end{array}$} & Do not agree & 11 & 8 \\
\hline & Rather do not agree & 8 & 16 \\
\hline & Rather agree & 22 & 31 \\
\hline & Agree & 59 & 45 \\
\hline \multirow{4}{*}{$\begin{array}{l}\text { Better understanding of } \\
\text { different processes }\end{array}$} & Do not agree & 3 & 8 \\
\hline & Rather do not agree * & 8 & 23 \\
\hline & Rather agree & 22 & 38 \\
\hline & Agree * & 67 & 31 \\
\hline \multirow{4}{*}{$\begin{array}{l}\text { Positive impact to the } \\
\text { acquisition of the study } \\
\text { content }\end{array}$} & Do not agree & 0 & 8 \\
\hline & Rather do not agree & 7 & 8 \\
\hline & Rather agree & 48 & 76 \\
\hline & Agree * & 45 & 8 \\
\hline
\end{tabular}

The majority of the surveyed students evaluate the positive impact of the use of ICT on the acquisition of the study content. Ninety-three percent of FT students and eighty-four percent of PT students rather or fully evaluate positive impact of the use of ICT on the acquisition of the study content. More FT students (45\%) in comparison with PT students ( $8 \%$ ) fully evaluate positive impact of the use of ICT on the acquisition of the study content. The results of the research suggest that the majority of pedagogical specialities students understand the necessity of acquiring ICT during study process.

A part of students also sees the negative impact of the use of ICT on the lifestyle or mutual relations (Table 4). Thirty-seven percent of FT students and forty-six percent of PT students agree that the use of ICT leads to the formation of addictions. The majority of students (66 \% of FT students and $70 \%$ of PT students) also agree that the use of ICT promotes sedentary lifestyle. There are different opinions of students about impact of the use of ICT on mutual relations of students. 
The negative impact of the use of ICT by students on the lifestyle or mutual relations (in $\%$ from the number of respondents) $(* p<0,05)$

\begin{tabular}{|c|c|c|c|}
\hline \multirow[t]{2}{*}{ Activities } & \multirow[t]{2}{*}{ Answer } & \multicolumn{2}{|c|}{ Groups of students } \\
\hline & & FT students & PT students \\
\hline \multirow{4}{*}{$\begin{array}{l}\text { Leads to the formation } \\
\text { of addictions }\end{array}$} & Do not agree * & 21 & 8 \\
\hline & Rather do not agree & 21 & 15 \\
\hline & Rather agree & 21 & 31 \\
\hline & Agree & 37 & 46 \\
\hline \multirow{4}{*}{$\begin{array}{c}\text { Promotes sedentary } \\
\text { lifestyle }\end{array}$} & Do not agree & 12 & 0 \\
\hline & Rather do not agree & 0 & 7 \\
\hline & Rather agree & 22 & 23 \\
\hline & Agree & 66 & 70 \\
\hline \multirow[t]{4}{*}{ Worsen mutual relations } & Do not agree & 20 & 15 \\
\hline & Rather do not agree & 26 & 31 \\
\hline & Rather agree & 30 & 23 \\
\hline & Agree & 24 & 31 \\
\hline
\end{tabular}

\section{Conclusions}

- The majority of surveyed pedagogical specialities students use ICT for study purposes 1-2 or 2$4 \mathrm{~h}$ during day. Different FT students use ICT more differently in comparison with PT students. FT students use ICT more than PT students for purposes not connected with study process. Many FT students $(56 \%)$ use ICT for purposes not connected with studies more than $4 \mathrm{~h}$ during day.

- FT students more often than PT students use ICT for different activities connected with study process: accomplish home works, contact with people for carrying out home works, make calculations for doing home works and keep up study e-environment. PT students in comparison with FT students more often use ICT for searching information to do home works.

- The majority of surveyed students evaluate their knowledge and skills in the using of ICT as good. More FT students (67\%) in comparison with PT students (31\%) are good in creating multimedia presentations.

- The majority of surveyed students agree or rather agree that the use of ICT gives positive impact on the different stages of study process. The use of ICT helps better involvement in the study process, makes students more independent during study process, gives them possibilities for better acquiring new information and better communication during study process, the use of ICT makes studies more exciting. More FT students (67\%) in comparison with PT students $(37 \%)$ agree that the use of ICT gives ability for better understanding of different processes. The majority of the surveyed students evaluate the positive impact of the use of ICT on the acquisition of the study content. More FT students (45\%) in comparison with PT students (8\%) fully evaluate positive impact of the use of ICT on the acquisition of the study content.

- The majority of surveyed students agree or rather agree to the negative impact of the use of ICT on the lifestyle: it leads to the formation of addictions, promotes sedentary lifestyle, and a part of students admit that the use of ICT worsen mutual relations.

\section{Bibliography}

1. Becta ICT Research. (2003). What the research says about ICT and motivation. British Educational Communications and Technology Agency (Becta). Retrieved from http://dera.ioe.ac.uk/14707/7/Research_Motivation_Redacted.pdf

2. Cullingford C., Haq N. (2009). Computers, Schools and Students: The Effects of Technology. ( $1^{\text {st }}$ ed.). Farnham, England: Routledge.

3. Dauvarte L., Dislere V. (2015). Didactic usability of the information communication technologies in Home economics and technology lessons. In V. Dislere (Ed.), The Proceedings of the 
International Scientific Conference Rural Environment. Education. Personality (REEP), 8. Jelgava: LLU TF, 188 - 197. Retrieved from http://lufb.llu.lv/conference/REEP/2015/LatviaUniv-Agricult-REEP-2015proceedings.pdf

4. Fichten C., Jorgensen M., Havel A., King L., Lussier A., Asuncion J., Budd J., Nguyen M.N., Amsel R. (2018). Information and Communication Technologies: Views of Canadian College Students and "Excellent" Professors. Journal of Education and Training Studies, 6(9), 1-12. Retrieved from https://eric.ed.gov/?id=EJ1184514

5. Fichten C.S., King L., Jorgensen M., Nguyen M.N., Budd J., Havel A., Asuncion J., Amsel R., Raymond O., Poldma T. (2015). What Do College Students Really Want When It Comes to Their Instructors' Use of Information and Communication Technologies (ICTs) in Their Teaching? International Journal of Learning, Teaching and Educational Research, 14(2), 173-191.

6. Gorghiu G., Gorghiu L.M., Pascale L. (2018). Enriching the ICT Competences of University Students - a Key Factor for Their Success as Future Teachers. Journal of Science and Arts. 18(1), 183-190.

7. Gumus S. (2013). Investigating the Factors Affecting Information and Communication Technology (ICT) Usage of Turkish Students in PISA 2009. Turkish Online Journal of Educational Technology - TOJET, 12(1), 102-107. Retrieved from https://eric.ed.gov/?id=EJ1008872

8. Hu X., Gong Y., Lai C., Leung F. (2018). The Relationship Between ICT and Student Literacy in Mathematics, Reading, and Science Across 44 Countries: A Multilevel Analysis. Computers and Education, 125, 1-13.

9. Ishtiag H., Qaiser S., Naseer D.M., Farhan S. (2017). Effects of Information and Communication Technology (ICT) on Students' Academic Achievement and Retention in Chemistry at Secondary Level. Journal of Education and Educational Development, 4(1), 73-93.

10. King L., Jorgensen M., Lussier A., Fichten C., Havel A., Amsel R., Poldma T., Budd J., Jorgensen S., Marcil E., Nguyen M.N., Chauvin A., Asuncion J. (2017). Student and Professor Perspectives on Exemplary Practices in the Use of Information and Communication Technologies (ICTs) and E-Learning in Colleges. Montreal, Canada: Adaptech Research Network. Retrieved from https://eric.ed.gov/?id=ED574860

11. Mamani L., Cipi E. (2013). Digital School as New Organization Based on Technologies of Information and Communication. European Scientific Journal. 4, 153-160. Retrieved from http://eujournal.org/index.php/esj/article/view/2468

12. Nettelbeck D. (2005). Computers, Thinking and Learning: Inspiring Students with Technology. Camberwell, Victoria: Australian Council for Education Research.

13. Nwosu J.C.; John H.C.; Izang A.A.; Akorede O.J. (2018). Assessment of Information and Communication Technology (ICT) Competence and Literacy Skills among Undergraduates as a Determinant Factor of Academic Achievement. Educational Research and Reviews, 13(15), 582-589.

14. Owusu-Ansah S. (2018). Adoption of Information Communication Technology (ICT) in Distance Education: A Retrospective Analysis. International Journal on E-Learning, 17(4), 527-550.

15. Racene A., Dislere V. (2014). Internet tools as a kind of career e-guidance. In V. Dislere (Ed.), The Proceedings of the International Scientific Conference Rural Environment. Education. Personality (REEP), 7. Jelgava: LLU TF, 200 - 207. Retrieved from http://llufb.llu.lv/conference/REEP/2014/Latvia-Univ-Agricult-REEP-2014proceedings.pdf

16. Sekar J.M.A., Lawrence A.S.A. (2015). Attitude of B.Ed. Students towards Information and Communication Technology (ICT). International Journal of Applied Research, 1(8), 785-787. Retrieved from https://files.eric.ed.gov/fulltext/ED582395.pdf 